\title{
"MATTI MATALAISEN" JULKEA EHDOTUS JA VÄHÄN MUUTAKIN
}

\begin{abstract}
Suomen kieltä monilla uudissanoilla rikastuttanut Wolmar SchildtKilpinen ujutteli 1840-luvulla kieleemme termejä yleisö ja julkiso. Niistä yleisö vakiintui käyttöön, julkiso sen sijaan ei. Artikkelissa pohditaan, mistä tämä johtuu. Ensi sijassa artikkelissa kuitenkin perustellaan eri tahoille suuntautuvien interventioiden pohjalta julkison käyttökelpoisuutta julkisuudessa keskusteleviin ja toimiviin viittaavana käsitteenä sekä oikaistaan eräitä yksipuolisia näkemyksiä tästä käsitteestä ja siihen nojautuvasta ajattelusta.
\end{abstract}

Tätä tulkintaa oikaisi samassa yhteydessä jo Kanawan toimittaja (Pietari Hannikainen). "Matti Matalainen" palasi asiaan vuoden 1847 numerossa 3. Ensinnäkin hän perusteli uusien suomen kielen sanojen tarvetta vertaamalla kielen kehitystä puun kasvuun. Kuten puu tarvitsee uudet oksansa, kielikin tarvitsee "sisäisen lakinsa mukaan" uudet sanansa - "aika-ihmisessä, liiotenkin walistuneessa, syntyy uusia sywempiä aatoksia, ja niitä hän uusilla sanoil-

Tiedotustutkimus $2006: 4$ 
la osoittelee”. Sanan yleisö taustaksi hän kertoi, että sana ylehensä tai yleensä "on hywin tawallinen", ja totesi, että niin kuin sana yhteinen "tulee sanasta $y h$ teensä [...] niin juontuu myöskin yleinen sanasta yleensä [...] kielenmukaisesti”. Todettakoon, että Häkkisen $(1987,393)$ mukaan sana yleinen on juuri kirjoittajan - Schildt-Kilpisen - vuonna 1836 esittämä uudissana.

Sitä, kuinka sana yleisö on juonnettavissa sanasta yleinen - kuten julkiso sanasta julkinen - "Matti Matalainen" kuvasi ja perusteli näin:

Nyt on sana Nuoriso (nuori wäki eli kansa) yleisesti käypä Karjalassa y.m. Sen mukaan owat sanat Julkiso (julkinen kansa), Yleisö (yleinen kansa) syntyneet.

Nimimerkki "Kanawan lukia" palasi asiaan vielä vuoden 1847 numerossa 7. Nyt hän puuttui erinäisiin muihin "Matalaisen" näkökohtiin, mutta jätti kysymyksen sanojen julkiso ja yleisö sopivuudesta suomeen "sillensä", koska huomasi kiistakumppaninsa pitävän niitä suomena "siitä syystä, että ne owat 'kielen lakien mukaan laadittu'”. Tässä tuoksahtaa ironia kuten siinäkin, että "Kanawan lukia" piti niitä puuhun ympättyinä "teko-oksina", jos "edes teko oksankaan" veroisina.

Mainitussa vuoden 1847 numeron 3 vastauksessaan "Matti Matalainen" tuki kantaansa sanojen julkiso ja yleisö sopivuudesta suomen kieleen muun muassa viittaamalla siihen, että niitä oli käytetty Kanawassa ennenkin. Ja - kuinka ollakaan - lehden vuoden 1845 numerosta 20 löytyy W. [Schildt-] Kilpisen kirjoitus, jossa hän kommentoi E.J. Kemellin Tuomas Kempiläisen Kristuksen seuraamisesta -kirjan suomennoksen kohtaloa muun muassa näin:

Kummastellen näemme ei mitään julkisesti sanotun eli päätellyn tästä kirjasta, waikka jo yhdeksän wuotta on ollut Yleisön eli Julkison käsissä. Lieneekö tämän kirjan kehnous, waiko julkisuus Suomessa, wai mikä syynä yleiseen wait-olemiseen? Ei kirja, eikä julkisuus ole siihen syynä, mutta kehno kirjakauppa maassamme.

Kirjoituksessaan Kilpinen paitsi mainosti Kemellin mielestään erinomaista suomennosta, selvästikin kokeili erinäisten uudissanojen istuvuutta suomenkieliseen esitykseen. Tätä osoittaa muun muassa se, että hän on varustanut katkelmassa kursivoidut sanat alaviitteillä, joissa hän kertoo vastaavat ruotsinkieliset termit: allmänhet (yleisö), publik (julkiso), publicitet (julkisuus) ja allmän (yleinen). ${ }^{2}$ - Muista "Matalaisen" mainitsemista Kanawan numeroista löytyi sana yleisö, mutta ei sanaa julkiso. Esimerkiksi vuoden 1845 numerossa 44 S. Soimanen (lienee kirjoitustyylistä päätellen taaskin Schildt-Kilpinen) arvioi suomalaisia sanomalehtiä ja totesi parista lehdestä näin:

Molemmat lehdet ansaitsewat tulla tutuiksi Suomen Yleisöltä, eli niiltä, joilla on kansan yleisessä elämässä tekemistä. Ja kukapa on niin sidottu, yksityiseen elämäänsä, ettei myöskin wähän julkisesta, yleisestä eläne; ei toki kukaan. 
Puheena olevista uudissanoista yleisö jäi eloon, julkiso sen sijaan ei. Syynä voi osaltaan olla, että vaikka Schildt-Kilpinen pyrki tekemään eroa niiden välillä - hänhän viittasi julkisolla julkiseen ja yleisöllä yleiseen kansaan ja luki edellisen ruotsin sanan publik ja jälkimmäisen sanan allmänbet vastineeksi - hän käytännössä piti niitä silti synonyymeinä ("Julkison eli Yleisön [...] vaatimus"; "Yleisön eli Julkison käsissä"). Termit kilpailivat siis käytännössä samasta merkityksestä. Vaakaa kallisti tällöin yleisön hyväksi ehkä se, että SchildtKilpinen näyttää itse suosineen sitä. Sehän juontui hänen sepittämästään yleinen-sanasta.

\section{JULKEASTA EHDOTUKSESTA}

Kun Seija Ridell ja minä ehdotimme vuonna 1998 sanan julkiso käyttöönottoa (Pietilä \& Ridell 1998), luulimme keksineemme aivan upouuden sanan. ${ }^{3}$ Meillä ei ollut aavistustakaan, että termiä oli yritetty ujuttaa kieleemme jo paljon aikaisemmin. Ehdotuksemme pontimena oli pulma, jonka Risto Kunelius (1997, 117) ilmaisi sanomalla, että suomen kielestä puuttuu kätevä tapa erottaa toisistaan yhtäältä ihmiset viestinnän tai ylipäänsä esitysten seuraajina ja vastaanottajina ja toisaalta ihmiset julkisesti keskustelevina ja toimivina muodostumina. Esimerkiksi englannin kielessä tämä ero voidaan periaatteessa tehdä termien audience ja public avulla viittaamalla edellisellä ihmisiin vastaanottajina ja jälkimmäisellä heihin julkisina toimijoina. Meillä siis vastaava eronteko hoituisi termeillä yleisö (audience) ja julkiso (public).

On erinomaisen kiinnostavaa, että jo 1800-luvun puolivälin Suomessa esitettiin tähän erotteluun luontuvat suomenkieliset sanat - vaikka niitä ei luotukaan tuon eron tekemiseksi. Noihin aikoihin tällaisen eron tekoon ei näytä olleen suuremmin tarvetta, oikeastaan hyvin ymmärrettävistä syistä. Suomihan oli tuolloin ja pitkään myöhemminkin ylhäältä alas jäsentynyt yhteiskunta, jossa julkinen toiminta kansallisuus- ja muine pyrkimyksineen oli kapean sivistyneistöeliitin harrastusta. Vaikka Suomesta on sanottu, että "kansanliikkeet loivat kansakunnan" (Alapuro \& Stenius 1989, 8), nuo liikkeet eivät olleet niinkään ruohonjuuritasolta omaehtoisesti versovaa kansalaisaktiivisuutta kuin eliitin ajamaa ja järjestämää toimintaa. Eliitin näkökulmasta kansa hahmottuikin luontevasti vastaanottavaiseksi ja osallistumaan mobilisoitavissa olevaksi yleisöksi (ks. Nieminen 2006).

Ylhäältä alaspäin jäsentynyt yhtenäisyys on saanut sittemmin väistyä moninaisten, julkisiksikin nousseiden ristiriitojen ja vastakkaisuuksien tieltä. On syntynyt myös perinteisistä, ylhäältä alas jäsentyvistä julkisen toiminnan muodoista eroavia kansalaisosallistumisen muotoja eli lisääntyvää pyrkimystä osallistua "itseä koskeviin asioihin suoremmin ja julkisemmin kuin edustuksellisen valmistelu- ja päätöksentekojärjestelmän kautta on perinteisesti ollut mahdollista" (Ridell 2004, 12; ks. myös Laine \& Peltonen 2003; Lehtinen \& Rannikko 1994; Rättilä 2001 ja Sutela 2001). Tässä toimijaroolissa ihmiset eivät enää ole asioita seuraavaa yleisöä. Mitä he ovat? Yksi vastausehdotus kuuluuः osallistuvaa yleisöä. Tätä sanaparia rasittavat kuitenkin ne konnotaatiot, joita perinne on iskostanut yleisötermiin ja joita valtavaksi paisunut mediayleisöys ruokkii: osallistuvakin yleisö hahmottuu vastaanottavaksi - se ottaa vastaan osallistumisensa ylhäältä annetut ehdot. Siten tullakseen päte- 
västi luonnehdituksi kansalaislähtöinen julkinen toiminta, millä areenalla se tapahtuukin, edellyttää muuta kuin yleisöpohjaista termiä. Aikoinaan tarkoitetta vaille jäänyt julkiso löytää tarkoitteensa tästä.

\section{AUDIENCE JA PUBLIC}

Kuten edellä sanoin, englannin kielessä nyt puheena oleva erottelu voidaan periaatteessa tehdä termien audience ja public avulla. Eri asia on, käytetäänkö niitä tällä tavoin. Eritoten public on monimerkityksinen - substantiivina se viittaa laajimmillaan johonkin väestöön tai ihmiskuntaan kokonaisuudessaan ja hiukan suppeammassa mielessä ihmisjoukkoon, jota luonnehtivat yhteiset piirteet ja kiinnostukset (ks. Livingstone (ed.) 2005, 217; vrt. myös OED XII 1989, 778). Jälkimmäisessä mielessä se voi viitata yhtä lailla johonkin vastaanottajayleisöön kuin julkisuudessa jonkin asian ympärillä toimiviin.

Selvittääkseni termin public käyttöä mediatutkimuksessa tein takavuosina tutkimuksen,jonkaaineistokoostuijoukosta englanninkielisiäyleisötutkimustekstejä (Pietilä 2000). ${ }^{4}$ Kävi ilmi, että milloin tätä termiä ylipäätään hyödynnettiin, sitä käytettiin useimmiten spontaanis-automaattisesti täsmentämättä termin merkitystä sen kummemmin. Vain harvoissa teksteissä siihen kiinnitettiin erityishuomiota vertaamalla sitä muihin termeihin, luonnehtimalla sitä jotenkin tai määrittelemällä se. Publicin näissä yleisötutkimusteksteissä saamat merkitykset voidaan jakaa karkeasti kahteen luokkaan. Useimmiten sillä viitattiin viestinten yleisöön, jolloin sen merkitys on pitkälti sama kuin termillä audience. Aika harvoin sitä hyödynnettiin audiencesta eroavassa merkityksessä. Näin käytettäessä siihen kiinnitettiin useinkin erityistä huomiota, kun taas sen käyttö audienceen rinnastuvassa merkityksessä oli lähes aina spontaanis-automaattista.

Tarkemmassa erittelyssä kävi ilmi, että publicin käyttö audienceen rinnastuvassa merkityksessä todennäköistyi tietynlaisissa yhteyksissä. Se nousi esiin useimmiten silloin, kun tarkastelu painottui menneisyyteen, kun viestinten yleisöstä puhuttiin hyvin laajassa mielessä, kun puhe kohdistui viestintäpolitiikkaan tai hallinnollisiin kysymyksiin tai kun tarkastelun kohteena olivat julkislaitokset (kuten julkisen palvelun yleisradio) tai demokratia ja politiikka yleensä. Nämä yhteydet sävyttävät publicin yleisönä vanhahtavaksi kyse on laajasta yhdentymästä (kansakunnasta), jota julkisviestimet ohjaavat poliittisissa ja muissa kysymyksissä holhoavasti ylhäältä päin. Suhteessa tähän audiencen tarkoittamaa yleisöä luonnehtivat tietysti vastakkaiset piirteet. ${ }^{5}$

Niihin harvahkoihin tapauksiin, joissa public erotettiin tavalla tai toisella audiencesta, on tarpeen syventyä hieman yksityiskohtaisemmin. Näihin tapauksiin en lue niitä, joissa termiä public käytetään yleisön piirissä erottamaan tietynlainen yleisö toisenlaisesta. Kaupallisten ja julkisen palvelun viestintäyhtiöiden yleisöpuhetta tutkittaessahan on havaittu, että julkinen palvelu puhuu vastaanottajistaan publicina korostaen tällä tavoin heitä kansalaisina (audience-as-public), kun taas kaupallinen viestintä puhuu vastaanottajistaan etupäässä kuluttajina (audience-as-market, ks. Ang 1991 ja Hellman 1999). Vaikka publicin määreeksi asetettaisiinkin tällöin julkisia asioita koskevan tiedon vastaanotto (ks. esim. Corner 1991), se viittaa silti vastaanottajayleisöön ja jää termin audience alatermiksi. 
Termien välillä alkaa ilmetä eroa sanottaessa esimerkiksi - kuten Hartley (1987, 185) - että televisio "pyrkii kääntämään audienceksi niin laajan kirjon publicista kuin mahdollista". Tässä public on varanto, josta viestimet ammentavat yleisöjä. Toisenlaisen esimerkin tarjoaa McCombs $(1998,33)$, jonka mielestä "tärkeä tulos audiencen uutiskokemuksista on se, että ajan mittaan public alkaa pitää keskeisinä uutisten kulloinkin korostamia asioita". Ihmiset ovat siis audience, yleisö, suhteessa uutisiin mutta public suhteessa keskeisinä pitämiinsä asioihin. Tällaisissa tapauksissa termejä käytetään spontaanis-automaattisesti kiinnittämättä niihin sen kummempaa huomiota. Seuraus on, että vaikka public erotetaankin audiencesta, se jää hyvin hahmottomaksi käsitteeksi. Sen tarkoittama ilmiö ei saa varsinaisesti omia ominaisuuksia.

Kuten ymmärrettävää onkin, nimenomaista huomiota näihin käsitteisiin kiinnitetään pyrittäessä täsmentämään niiden suhdetta ja tekemään niiden mahdollinen ero selväksi. Niinpä Dahlgrenille $(1995,19)$ public "on olemassa diskursiivisena vuorovaikutusprosessina", joten "erilliset, viestimiä kotonaan kuluttavat yksilöt eivät ole public" vaan "pelkästään media-audience". Hän vaatiikin toimittajia edistämään "vuorovaikutusta audiencen piirissä" ja auttamaan yleisön jäseniä "astumaan asemansa 'audiencena' ylittäen vuorovaikutukseen kansalaisina" (mt., 50). Näin hän piirtää periaatteessa selvän rajan publicin ja audiencen väliin. Auki tosin jää, millaista vuorovaikutusta publicin rakentuminen edellyttää.

Dahlgrenia innoittivat Jürgen Habermasin (1962/2004) ajatukset julkisuudesta. Ne inspiroivat myös Livingstonea ja Luntia (1994), joista public on olemassa yksityishenkilöiden vapaana ja tasa-arvoisena kriittis-järkiperäisenä keskusteluna julkisuudessa. Tällä teoreettisella tasolla he erottavat publicin audiencesta ja yleisöpositiosta ylisummaan viimeistäänkin hahmotellessaan visiotaan osallistuvasta demokratiasta, jossa "poliittisen osallistumisen tärkeäksi ulottuvuudeksi tulee se, että public valvoo viestinten tuotantoprosessia ja voi osallistua siihen" (mt., 12).

Tätä luonnehdintaa he soveltavat television talk show -ohjelmiin. Niissä esiintyvät ovat public ollessaan julkisesti keskusteleva joukko, joka osallistuu "viestimen tuotantoprosessiin", jos kohta media-ammattilaisten kaitsemina ${ }^{6}$ Livingstone ja Lunt ajautuvat kuitenkin vaikeuksiin yrittäessään venyttää luonnehdintaansa myös noiden ohjelmien katsojiin. Heistä katselu muuttaa katsojat jollain tavoin publicin jäseniksi: ohjelmissa ilmaistut "moninaiset näkemykset" tarjoavat "katsojille aktiivisen roolin väittelyssä" (mt., 30). Katsojat eivät kuitenkaan ole - kuten Price $(1995,29)$ huomauttaa - "mukana oleva osapuoli", vaan he osallistuvat "väittelyyn vain välillisesti, vain sen seuraajina". Audience voi olla potentiaalinen mutta ei vielä aktuaalinen public.

Livingstone ja Lunt tekevät joka tapauksessa selväksi, että public voidaan yleisötutkimuksenkin kannalta erottaa selvästi audiencesta. Niin tekee myös McQuail (1987, 219) määritellessään publicin tarkoittavan "aktiivista, vuorovaikutteista ja pitkälti itsenäistä ryhmää, jota tietyt viestimet palvelevat mutta jonka olemassaolo ei riipu niistä". Myöhemmässä kirjassaan hän antaa esimerkkejä tällaisista publiceista (McQuail 1997, 26-30). Asteikolla, jolla aidon publicin piirteet vähenevät vaihe vaiheelta, ne ulottuvat vaihtoehtoliikkeistä poliittisten ja uskonnollisten ryhmien sekä paikallisyhteisöjen kautta julkisen palvelun viestintää seuraavaan laajaan publiciin. Nämä esimerkit asettuvat osin kitkaiseen suhteeseen 
esitetyn määritelmän kanssa: jos asteikon alkupään tapaukset vielä ovatkin sovitettavissa siihen, loppupään tapaukset eivät ole - jo paikallisyhteisöä on vaikea mieltää määritelmän kuvaamaksi ryhmäksi, ja julkisen palvelun viestintää seuraavan yleisön mieltäminen sellaiseksi on mahdotonta.

Jensen $(1990,130)$ puolestaan pohtii sosiaalisen toiminnan näkökulmasta, voiko "audienceista muodostua myös eduiltaan yhteisiä sosiaalisia toimijoita, publiceja”. Tätä tutkiakseen hän perusti niin kutsuttuja tulevaisuustyöpajoja, joiden tehtävänä oli keskustella televisiosta. Tulos oli, että tällaisilla "ryhmillä on kykyä toimia publiceina", sillä ne pystyivät keskusteluissaan kehittelemään kriittisiä näkökulmia televisioon (mt., 142). Myös Turowin (1992, 124-151) mielestä yksilöt tai järjestäytyneet ryhmät muodostavat publiceja pyrkiessään vaikuttamaan viestimiin. Vaikka public jääkin näissä viimeksi esitetyissä tapauksissa erityislaatuiseksi, se joka tapauksessa määrittyy viestintäprosessissa toimivaksi eikä jää audiencen tavoin vastaanottavaksi tahoksi.

\section{ENTÄPÄ MUUT KIELET?}

Se tulos, että termillä public ei kovin usein viitattu julkisuuden toimijoihin, on hyvin ymmärrettävä - edustivathan tutkitut tekstit median vastaanottoon keskittynyttä yleisötutkimusta. Tulosta tasapainottaa se, että muun muassa poliittisen viestinnän ja journalismin tutkimuksessa termi tavataan monestikin mielessä tai toisessa julkisesti toimiviin kansalaisiin viittaavana. Esimerkiksi ilmaisussa public journalism termi public alleviivaa tavallisten ihmisten näkemysten pääsyä journalismin areenalle, jolloin he osallistuvat "viestinten tuotantoprosessiin" jäämättä vain vastaanottavaksi audienceksi. Tosin osallistuminen toteutuu toimittajien asettamissa puitteissa.

Yllä kuvatun tutkimuksen tärkeimpänä tuloksena voidaan itse asiassa pitää viitteitä siitä, että public on menettämässä merkitystään yleisöterminä (ks. myös McQuail 1997, 137-138). Tämä avaa mediatutkimukselle mahdollisuuksia artikuloida sitä yhä nimenomaisemmin terminä, joka viittaa vastaanottajien asemesta julkisuudessa toimiviin - niihin, joista suomen kielessä voidaan käyttää Schildt-Kilpisen mainiota termiä julkiso. Jos englannissa ja suomessa on tarjolla termistö tässä puheena olevan analyyttisen eron tekemiseksi, mikä lienee tilanne muissa kielissä?

Hiljattain Sonia Livingstonen toimittamana ilmestyneen kokoomateoksen Audiences and Publics (2005) liitteeksi on koottu sanakirjapohjaisia havaintoja siitä, kuinka erinäisissä eurooppalaisissa kielissä pyritään selviytymään käsillä olevan semanttisen kentän hallintaongelmista. Esillä ovat Livingstonen käsittelemän englannin lisäksi saksa (Ulrike Meinhof), tanska (Kirsten Drotner), kreikka (Mirca Madianou), slovenia (Sabina Mihelj) ja ranska (Daniel Dayan). Livingstonen englantia koskevista huomioista on tässä syytä nostaa esiin se, että termin public tavallisista sanakirjamerkityksistä ei juuri löydy viittauksia kansalaisten julkiseen toimintaan. Julkisoon viittaavassa merkityksessä termiä onkin viljelty lähes yksinomaan akateemisissa diskursseissa.

Myöskään muissa esillä olevissa kielissä termin public vastineiksi ilmoitettujen termien yleiset sanakirjamerkitykset eivät nosta esiin julkisoutta eli kansalaisten julkista toimeliaisuutta - tai ainakaan noista merkityksistä selkoa tekevät eivät tuo tätä esiin. ${ }^{8}$ Selontekijät eivät mainitse myöskään, että heidän 
omien kieltensä akateemisissa diskursseissa kyseisiä termejä viljeltäisiin tässä merkityksessä. Tuntuu kuitenkin vaikealta ajatella, että näin ei tehtäisi. Joka tapauksessa on selvää, että käsillä olevissa kielissä on tapoja puhua julkisesta toimijuudesta, vaikka käytössä ei olisikaan yhtä nimenomaista, toimijat piiriinsä sulkevaa julkiso-tyyppistä substantiivia.

Toinen merkille pantava seikka on se, että näistä muista kielistä puuttuu englannin audiencen tapainen, nimenomaan viestinten yleisöön viittaavaksi tarkoitettu yleinen termi. Niissä toki on puheena olevaan semanttiseen kenttään viittaavia yleistermejä, mutta ne kattavat sekä audiencen että publicin alueet eli ovat käännettävissä englanniksi asianyhteydestä riippuen jommallakummalla termillä. ${ }^{9}$ Tällaisten yleistermien lisäksi näissä kielessä on vaihtelevasti niin julkisuuteen kuin välinekohtaisiin yleisöihinkin viittaavia erityistermejä, mutta niistä ei yhdessäkään tapauksessa rakennu englannin audience vs. public -asetelmaan rinnastuvaa erottelukuviota.

\section{JULKINEN JA YKSITYINEN YLEISÖ}

Mosco ja Kaye (2000) kertovat audiencen nousseen englannissa varsinaiseksi viestinten yleisöön viittaavaksi yleistermiksi vasta noin 1920 -luvulta lähtien. ${ }^{10}$ Ennen tätä termi public lienee ollut englannissa samalla tavoin monimerkityksinen termi kuin termit public ranskassa ja Publikum saksassa. Se, mistä historiallisista yhteyksistä näissä yleistermeissä risteävät erisuuntaiset merkitysulottuvuudet ovat peräisin, on tietysti vaikea kysymys, jonka selvittäminen vaatisi seikkaperäistä kielihistoriallista tutkimusta. Rohkenen silti esittää tästä aiheesta joitakin pohdintoja lähtökohtanani Jürgen Habermasin Julkisuuden rakennemuutos -kirjassaan esittämät näkökohdat kirjallisesta julkisuudesta ja sen muotoutumiseen liittyvistä seikoista.

Habermas $(1962 / 2004,62)$ kertoo Auerbachiin viitaten, että ranskan substantiivi public laajeni kattamaan yleisön 1600-luvun alkupuolella, kun termiä alettiin käyttää teatteriesitysten seuraajista. Tätä ennen sillä oli viitattu yksinomaan valtioon tai yhteiseen hyvään. Saksassakin alun perin julkisen vallan alueelle viitannut Publikum laajeni yleisötermiksi, kun se sai lisätarkoitteekseen 1700-luvulla teatterissa kävijät (mt,, 34, 73). Teatteriesityksethän ovat julkisia tilaisuuksia, ja niitä seuraavat ovat samassa tilassa läsnä olevaa julkista yleisöä. Sama pätee konserttiesityksiin. Taidenäyttelyissä kävijöitäkin voidaan pitää julkisena yleisönä. 1700-luvulla jopa kirjojen ja muun painetun sanan lukemiseen liittyi usein julkinen tai ainakin sosiaalinen puolensa - oli yhteisiä lukuseuroja ja -piirejä, sanomalehtiä tilattiin ja luettiin yhdessä ja niin edespäin. (mt., 89, 118-119, 243). Tältä kannalta ei ole ihme, että kulttuurin kuluttajiin alettiin viitata termillä, joka yksityisyyden vastakohtana viittasi julkiseen.

Habermasin mukaan tähän julkiseen yleisöyteen liittyi tärkeänä osana keskustelu nähdystä, kuullusta ja luetusta. 1700-luvun lukevalle yleisölle olikin tyypillistä, että sen muodostaneet "yksityishenkilöt kokoontuivat julkisoksi" pohtimaan lukemaansa julkisesti (mt., 89). Julkista keskustelua käytiin toki muunkin kulttuurituotannon kuin kirjallisuuden tiimoilta. Tällaisten keskustelujen virittämästä julkisuudesta Habermas puhuu kirjallisena julkisuutena. Richard Butsch (2000) täydentää ja radikalisoi Habermasin piirtämää kuvaa 
kertomalla, että esimerkiksi Englannin ja Yhdysvaltain teatterit olivat vielä 1800-luvun alussa osa julkisuutta. Paikalla olijat osallistuivat itse esityksiin ja kävivät esityksistä usein paljoa piittaamatta julkista keskustelua jopa politiikasta. "Siten varhaiset teatterissa kävijät - tai usein ryhmittymät heidän joukossaan - lyöttäytyivät keskenään väitteleviksi tai kollektiivisesti toimiviksi poliittisiksi kuppikunniksi. Näin teatterista tuli julkinen keskustelu- ja toiminta-areena" (mt, 8). Tuolloisissa kulttuurin kuluttajaryhmissä risteytyi siten kaksi erilaista ulottuvuutta - yleisöulottuvuus ja julkisoulottuvuus.

Mainitussa kirjassaan Habermas viittaa termillä Publikum sekä kulttuurituotteiden ja viestinten vastaanottajiin että julkisuudessa yleisesti kiinnostavista aiheista kuten taiteesta, politiikasta ynnä muusta keskusteleviin henkilöihin. ${ }^{11}$ Toisaalta Meinhof ei mainitse Livingstonen kirjaan laatimassaan katsauksessa tämän termin nykyisiin sanakirjamerkityksiin, että sitä käytettäisiin myös julkisomerkityksessä. Itse asiassa termi painottuu Meinhofin mukaan nykyään voimakkaasti yleisön suuntaan. Tämä saattaa heijastella Habermasin kuvaamaa julkisuuden rakennemuutosta - sitä, että sitten klassisen porvarillisen julkisuuden kauden julkisous on paljolti näivettynyt samalla kun varsinkin viestinten yleisönä oleminen on valtavasti laajentunut ja painopiste sen piirissä on siirtynyt julkisesta yksityiseen yleisöyteen. ${ }^{12}$

Tämä painopisteen siirtymä on esimerkiksi niin James Careyn $(1989,116)$ kuin hänen tässä yhteydessä tulkitsemansa Harold Innisin mukaan tulosta modernien viestinten kehityksestä:

Modernit viestimet loivat paljolti taloudellisiin tarkoituksiin viestintäjärjestelmän, joka oli olennaisesti yksityinen. Julkiso [public], jollainen muodostui lukevista ja lukemastaan julkisesti keskustelevista ja väittelevistä ihmisistä, syrjäytyi yksityisen lukemisen ja lukevan yleisön [audience] tieltä.

Tämän kehityksen voi ajatella käynnistyneen sitä mukaa kuin sanomalehdistöstä tuli 1800 -luvulla massamittainen viestin. ${ }^{13}$ Ratkaisevasti yleisöyden yksityistymiseen lienevät kuitenkin vaikuttaneet radion leviäminen 1920ja 1930-luvuilla sekä television läpimurto 1950- ja 1960-luvuilla. Audiencen nousu varsinaiseksi viestinten yleisöön viittaavaksi termiksi englannissa 1920-luvulta lähtien on kytkettävissä luontevasti juuri yleisöyden painopistesiirtymään. Nimittäin viestinten yleisöön viittaavana yleisterminäkin se silti painottuu yksityisen yleisön suuntaan - näin ainakin suhteessa public-termillä vielä olevaan yleisömerkitykseen, jossa painottuu julkinen yleisö.

\section{ONKO JULKISO TARPEETON KÄSITE?}

Oma kysymyksensä on, miksi tuo painopistesiirtymä ei ole saanut muissa tarkastelluissa kielissä aikaan sellaista terminologista kehitystä, joka audience vs. public -asetelman tavoin mahdollistaisi yleisön ja julkison analyyttisen erottamisen toisistaan. Tähän minulla ei ole edes spekulatiivista vastausta. Sen sijaan pohdin hiukan sitä, miksi yleisön ja julkison eroon ei useinkaan kiinnitetä huomiota tai miksi huomion kiinnittämistä siihen pidetään turhanaikaisena ja sen käsitteellistämistä teennäisenä sanahelinänä. Tämä saattaa johtua 
siitä, että julkisoudeksi nimittämäni seikka on tietyltä kannalta vain yleisön 'toisin olemista'. Hyvä esimerkki on näkemästään teatteriesityksestä julkisesti keskusteleva seurue: sehän on tällöin vain siirtynyt vastaanottavan yleisön olotilasta keskustelevan yleisön olotilaan. Tarvitaanko asiasta puhumiseksi näin ollen eri termejä?

Daniel Dayan (2005, ks. myös 2001), joka tarkastelee asiaa juuri kiertona näiden olotilojen välillä, vastaa kysymykseen myöntävästi. Hänelle viestinten annin vastaanottajat ovat yleisö (audience). Jos kuitenkin jokin viestinten kertoma saa jotkut yleisön jäsenet reagoimaan julkisesti, heistä rakentuu julkison (public) itu. Varsinaiseksi julkisoksi itu kasvaa silti vasta kun siitä rakentuu julkisesti toimiva, "luonteeltaan kollektiivinen, yhtenäinen yksikkö, ensemble, jota luonnehtii yhteinen sosiaalisuus, yhteinen identiteetti ja taju tästä identiteetistä" (mt., 46). Tämän julkison jäsenet voivat sitten palata ajoittain yleisöksi seuratessaan viestimistä toimintansa kulkua.

Dayanin katse kohdistuu kuitenkin liiaksi kahden olotilan välillä kiertävään rybmään. Siten häntä vastaan voidaan yhä väittää, että hänen julkisoksi nimittämässään ei ole kyse muusta kuin yleisön 'toisin olemisesta'. Tästä vastaväitteestä vapaudutaan vain irrottamalla katse ryhmästä, jonka jäsenet ovat milloin sitä, milloin tätä, ja kohdistamalla se niihin seikkoihin, jotka konstituoivat tuon olemisen milloin siksi, milloin täksi - toisin sanoen kohdistamalla se yleisöyttä ja julkisoutta rakentaviin kollektiivisiin vuorovaikutus- ja käyttäytymismuotoibin. Näin tullaan Pricen $(1992,23)$ "julkison [public] diskursiiviseksi malliksi" kutsumaan julkison käsittämistapaan.

Tätä käsittämistapaa on kehitelty etenkin kollektiivista käyttäytymistä koskevan ajattelun piirissä. Sen lähtökohdat palautuvat 1800-luvun joukkopsykologiaan ja eritoten Gabriel Tarden ajatteluun. Missä joukkopsykologian toinen keskeinen edustaja, Gustave Le Bon, näki yhteiskunnassa pelkästään joukkoja, siinä Tarde (1898, 1901/1969) erotti toisistaan joukon ja julkison. Kun joukon yhteys syntyy fyysisestä läsnäolosta samassa tilassa, julkison yhteys on pelkästään henkistä, joten sen jäsenet voivat olla fyysisesti toisistaan erillään. Tällainen yhteys solmiutuu esimerkiksi kun sanomalehti synnyttää jonkin vakaumuksen tai intohimon samanaikaisesti monissa ihmisissä.

Robert E. Park (1904/1972, 80) tarkensi erottelua joukon ja julkison välillä lähtien niiden pohjana olevista vuorovaikutus- ja käyttäytymismuodoista: "missä joukko antautuu yhteisen vietin valtaan ja noudattaa sitä kritiikittömästi", siinä mielipiteiltään erilaisista ihmisistä koostuvaa julkisoa "ohjaa harkitsevuus ja järkiperäinen pohdinta". Julkisolle ominainen vuorovaikutusmuoto onkin kriittinen keskustelu. Tähtäimenä tällöin on ratkaista se ongelma tai sovitella se ristiriita, joka alun perin sai ihmiset kokoontumaan julkisoksi. Koska keskustelu voi olla välillistä, julkiso voi koostua Tarden edellyttämään tapaan erillään olevista ihmisistä.

Tätä ajatustapaa kehittelivät muun muassa John Dewey (1927), Herbert Blumer (1946/1999 ja 1947/1965) ja C. Wright Mills (1956/1999 ja 1963), kukin omalla tavallaan (ks. V. Pietilä 1999). Heistä Blumer (1946/1999, 21) määritteli julkison ryhmäksi, "(a) joka on kasvokkain jonkin kysymyksen kanssa, (b) joka on eri mieltä siitä, kuinka sitä on käsiteltävä, ja (c) joka on antautunut keskustelemaan asiasta". Julkiso pyrkii löytämään asiaan ratkaisun tai muodostamaan siitä julkisen mielipiteen ohjaamaan niiden toimintaa, joiden hoidettaviin tuo asia kuuluu (Blumer 1947/1965). Seuraava määritelmä kiteyttää yhteen joukon aiempia näkemyksiä (Turner \& Killian 1972, 179): 
Julkiso on erillään olevien ihmisten ryhmä. Näitä ihmisiä kiinnostaa sama kysymys, mutta he ovat siitä eri mieltä. He keskustelevat siitä pyrkimyksenään päästä yhteiseen mielipiteeseen, jonka he odottavat vaikuttavan siihen, kuinka jokin yksilö tai ryhmä toimii.

Missä julkison kollektiivista käyttäytymistä luonnehtii julkinen ja etupäässä keskustelullinen vuorovaikutus, siinä yleisön käyttäytyminen on kollektiivisen käyttäytymisen teorian termein massakäyttäytymistä, jota luonnehtii keskinäisen vuorovaikutuksen ja kokemusten vaihdon niukkuus (Blumer 1946/1999, 19). ${ }^{14}$ Massakäyttäytymisen piirissä ihmiset ovat toisistaan erillään eikä heidän välillään ole sellaisia yhteyksiä kuin julkisossa. Esimerkiksi televisiota kotonaan katsova voi hyvinkin mieltää, että hänen lisäkseen samaa ohjelmaa katsovat hänen kotipiirinsä ulkopuolella tuhannet muut, mutta hän ei ole yhteydessä kehenkään heistä.

Kollektiivisen käyttäytymisen teoreetikkojen mukaan sellaiset kollektiivimuodostumat kuin julkisot ja massat ovat vakiintumattomia. $\mathrm{Ne}$ ovat jatkuvasti syntyviä ja purkautuvia toisin kuin vaikkapa organisoituneet yhteiskunnalliset liikkeet järjestöistä ja yhdistyksistä puhumattakaan. Niinpä esimerkiksi Dayan $(2005,46)$ tulee edellisessä luonnehdinnassaan pitäneeksi julkisoja liian kiinteinä muodostumina. ${ }^{15}$ Voi jopa väittää, että puhe julkisoista ryhminä tai kollektiiveina on ylipäätään omiaan esineistämään ne liian oliomaisiksi, jolloin näköpiiristä alkaa kadota se, että ne eivät ole pysyviä pysyvää on vain se vuorovaikutus- ja käyttäytymismuoto, jonka pohjalle ne rakentuvat. Julkisoudessa onkin kyse astumisesta tällaiseen käyttäytymismuotoon (tai rooliin), yleisöydessä vastaavasti astumisesta sen konstituoivaan käyttäytymismuotoon (tai rooliin).

John Fiske (1994) on eräässä yhteydessä luonut substantiivin audience rinnalle verbin to audience (yleisöityä) ja verbikantaisen substantiivijohdoksen audiencing (yleisöityminen). Tämä korostaa sitä, että yleisöt eivät ole selvärajaisia olioita vaan että yleisöyttä voidaan lähestyä dynaamisena prosessina, jatkuvasti solmiutuvina ja purkautuvina suhteina viestimiin ja ylipäänsä esityksiin. Georg Simmel (1908, 1917/1999) ajatteli aikoinaan samaan suuntaan yhteiskunnasta. Hänestä se on kiinteiltä näyttävistä muodostumistaan huolimatta ihmisten välillä solmiutuvaa ja purkautuvaa vuorovaikutusta, joten "ei pitäisikään puhua yhteiskunnasta vaan yhteiskunnallistumisesta" (mt,, 79; ks. myös K. Pietilä \& Sondermann 1994, 19-24 ja 36-40). Jos yhteiskunta on kiinteän olion sijasta jatkuvasti vaihtelevaa yhteiskunnallistumista tai yhteiskuntaistumista, yleisö olisi vastaavasti yleisöitymistä ja julkiso julkisoitumista. Tämä ei tietenkään merkitse, että substantiivimuodot kävisivät tarpeettomiksi. Kyse on vain niiden suhteellistamisesta.

\section{JULKISOUS - PELKKÄÄ JÄRKEILYÄKÖ?}

Julkisous on siis julkisen vuorovaikutuksen virittämistä tai sellaiseen osallistumista puuttumalla julkisesti sanoin tai teoin johonkin asiaan. Kuuluuko kaikki julkinen vuorovaikutus tämän käsitteen piiriin vai edellytetäänkö siltä joitakin erityispiirteitä? Onko sen oltava nimenomaan rationaalista keskustelua eli järkeilyä 'vakavista' poliittisista kysymyksistä? 
Anu Koivunen ja Mikko Lehtonen (2005) tulkitsivat äskettäin julkisolähtöistä käsitystä tähän suuntaan pitäen sitä raskaasti yksipuolisena, jopa halvauttavana: se korostaa järkeä muun kustannuksella, se rakentuu "oikeuksien, velvollisuuksien ja tarpeiden" sanastolle affektit ja halut sivuuttaen (mt, 10), se "olettaa valistuksen itseidenttisen subjektin" ja unohtaa subjektin sisäisen jakautuneisuuden (mt, 11) ja asettaa " julkisuuden, median ja kansalaisuuden" hierarkkiseen ja normatiiviseen kytkökseen (mt., 12). Kirjoittajat vaativatkin, että "[j]ulkisuus/julkiso on syytä käsitteellistää uudelleen" (mt., 12). Omassa käsitteellistysehdotuksessaan he kuitenkin palauttavat julkisuuden - jos kohta eri areenoiksi jaettuna - tutuksi suhteeksi viestimistä yleisöön, jossa viestimet puhuttelevat ja yleisö on puhuttelujen kohde. Julkinen vuorovaikutus sanan varsinaisessa mielessä on ehdotuksesta lähes tyystin poissa.

Kirjoittajien käsitys julkisoajattelusta perustuu heidän Habermas-luentaansa, joka kuitenkin tuntuu olevan peräisin pikemmin toisen käden Habermaskritiikistä kuin kritiikin kohteen itsensä lukemisesta. Täydentäisinkin heidän luentaansa parilla näkökohdalla. Kehitellessään loogisia ehtoja keskustelulle, joka mahdollistaa päätymisen järkiperäiseen yhteisymmärrykseen, Habermas (ks. esim. 1990/2004, 388-390) toki painottaa rationaalisuutta, mutta tämä sinänsä ei sulje normatiivisellakaan tasolla pois muunlaista ainesta - sikäli kuin se ei sodi sanottuja ehtoja vastaan ja tee keskustelusta järjetöntä. Toiseksi nämä normatiiviset ehdot eivät määrittele keskustelua empiirisenä ilmiönä vaan tarjoavat mittapuita sen arvioimiseksi. Kolmanneksi Habermas (1997, 372-375 ja 435-467) erottaa päätöksentekoon suuntautuvan (lähinnä parlamenttitasoisen) keskustelun sille neuvoa-antavasta, epämuodollisesta julkisesta keskustelusta ja katsoo, että normatiivisia mittapuita on mielekästä soveltaa vain edelliseen. Siten jopa Habermasin mukaan julkinen keskustelu voi olla empiirisesti sangen moninaista.

Toisaalta ainakaan oma julkisokäsitykseni ei perustu Habermasiin vaan edellä mainittuun julkison diskursiiviseen malliin. Sitäkin olen väljentänyt edellyttämällä julkisoutta määrittäviltä asioihin puuttumisilta vain sitä, että ne pyrkivät tai osallistuvat julkiseen vuorovaikutukseen ja ylittävät oman henkilökohtaisen maailman. Keskustelu, joka pyörii omissa kokemuksissa hakematta yhtymäkohtia mihinkään yleisempään tai kytkeytymättä julkisuudessa esiintyviin diskursseihin, on yksityistä, vaikka sitä käytäisiin julkisesti. Jos julkiseen keskusteluun taas luettaisiin vain Habermasin diskurssieettiset kriteerit edes osapuilleen täyttävät puheenvuorot, moni relevantti puheenvuoro jäisi ottamatta lukuun. Ei tieteellisessäkään keskustelussa ole tavatonta, että esimerkiksi vastapuolista luodaan ennakkoluuloihin ja stereotypioihin perustuvia olkiukkoja sen sijaan että sensitiivisesti kuunnellen pyrittäisiin ymmärtämään, mitä he tahtovat sanoa, ja punnittaisiin tätä järkiperäisin kriteerein.

Toisin kuin Koivunen ja Lehtonen (2005) antavat ymmärtää, julkisokäsite ylittää heidän 'habermasilaisuuden' ja 'fiskeläisyyden' välille rakentamansa olkiukkovastakkaisuuden. Luetaanpa Ridelliä (1999, 32):

On oleellista huomata, että kysymys julkisosta ei rajoitu virallisen poliittisen kansalaisuuden alueelle eikä eroa dikotomisesti kuluttajuuden problematiikasta vaan avaa myös jälkimmäiseen omanlaisensa näkökulman. Julkison tärkeyden korostaminen ei myöskään tarkoita, että yleisöyden tutkimus olisi syytä hylätä. Yleisönä toi- 
miminen - osana kuluttamiseen ja kuluttajuuteen perustuvaa elä-

mäntapaaa - tulisi kuitenkin problematisoida ja politisoida [...].

Vaikka julkisoutta onkin tähän mennessä pohdittu ja tutkittu etupäässä suhteessa sellaisiin 'vakaviin' kysymyksiin kuin valtion budjetti (Reunanen 2003) tai kaavoituskysymykset (V. Pietilä 2002; Ridell 2005), tutkittavaa julkisoitumista synnyttävät myös sellaiset aiheet kuin vaikkapa susikanta, lihavuus, tosi-tv-ohjelmat tai pulmat, joita kännissä suihkuun nukahtavista aiheutuu. Michael Warnerin (2002) tavoin voisi sanoa, että aiheet tai diskurssit virittävät omat julkisonsa. ${ }^{16}$ Toisaalta vaikuttaa myös siltä, että eri keskustelufoorumit kokoavat piiriinsä omia julkisojaan (V. Pietilä 2001, 20-21 ja 2002b, 346-348). Aiheen tuottama tai foorumilla rakentuva julkisoituminen tulee empiirisesti havaittavaksi sitä koskevina julkisina puheenvuoroina tai muina puuttumisina. Kuten aikoinani sanoin (V. Pietilä 1999, 10)

[p]uheenvuorot voivat sisältyä yhtä lailla fiktioon kuin faktaankin. Tiettyä kiistanalaista asiaa käsittelevä saippuaoopperan jakso on sitä koskeva julkinen puheenvuoro siinä kuin ministerin sitä koskeva lausunto tai asiaa koskettaneen henkilön kertomus kokemastaan television keskusteluohjelmassa.

Edustaneeko tämä sitä julkison/kansalaisen suojaamista "kaupallisuudelta ja viihteellisyydeltä", josta Koivunen ja Lehtonen $(2005,10)$ tekevät minut vastuulliseksi?

\section{TAKAISIN 1800-LUVULLE}

Koska aloitin tämän artikkelin 1800-luvulla kieleemme ehdotetuista uudissanoista julkiso ja yleisö, on perusteltua päättää se tuolloin esitettyihin näkökohtiin julkisesta keskustelusta. Kukin voi tykönänsä miettiä, onko niillä jotain sanottavaa nykyiselle, postmoderniksikin kutsutulle ajallemme.

Edellyttäessään sanomalehdistöltä julkisen tai yleisen mielipiteen edustamista J. V. Snellman $(1844 / 2005,306)$ pohti Saima-lehden kirjoituksessaan "Julkinen sana" asiaa näin:

Tietenkin käy niin, että julkisen sanan eri äänenkannattajat tavoittavat yleisen mielipiteen eri tavoin. Tällainen osoittaa vain sitä, että yleisen mielipiteen sisällä on erilaisia ryhmäkuntia. Ja mitenkä se muuten voisi ollakaan? Kuka lopulta saa selville, mikä mielipide on oikea julkinen mielipide? Kunakin hetkenä on jokaisen tietysti omasta puolestaan ratkaistava, mikä mielipide on järkevin ja siksi yleisin. Tässä ratkaisussa auttaa julkinen keskustelu. Mutta varman arvion voi esittää vasta tulevaisuus, kun edellisen ajan mielipide on jo muuttunut laiksi ja olemassa oleviksi julkisiksi instituutioiksi. 
Tätä on kiinnostava verrata Habermasin (1962/2004) hahmotelmaan klassisesta porvarillisesta julkisuudesta. Ensinnäkin Snellmanin antama paino julkiselle keskustelulle mielipidekysymyksissä vastaa näkemystä siitä, että julkinen keskustelu, jossa argumentit ratkaisevat, on porvarillisen julkisuuden perustava toimintatapa (mt, 57, 69 ja passim.). Tuon julkisuuden itseymmärrys piti keskustelussa syntyvää julkista mielipidettä lakien ainoana laillisena lähteenä (mt., 93). Snellman katsoo samaten, että keskusteluissa ansiokkaimmiksi osoittautuneet mielipiteet muuttuvat sittemmin laeiksi ja muiksi julkisiksi laitoksiksi.

Näistä yhtäläisyyksistä huolimatta Snellmanin näkemys julkisuudesta näyttää tietyissä suhteissa eroavan klassisen porvarillisen julkisuuden mallista. Näet missä porvarillinen julkisuus rakentui viime kädessä yhtenevälle porvarilliselle luokkaedulle (mt., 137, 261-263) ja sen karsinoimalle mielipidekentälle, siinä Snellman huomaa julkisuudessa erilaisia mielipiteitä. Ero ei tosin tässä vaikuta järin merkittävältä, mutta näyttää selvenevän siirryttäessä kysymykseen, mitä julkisuuteen astuminen edellyttää. Kun astuminen porvarilliseen julkisuuteen edellytti Habermasin (mt., 94-95 ja passim.) mukaan sivistystä ja omaisuutta, Snellman (1846/2005, 93-94) katsoo Saima-lehden kirjoituksessaan "Yleinen mielipide", että julkiseen keskusteluun osallistuminen edellyttää yleissivistystä ja (omaisuuden sijasta) jonkin elämänalueen erityistuntemusta.

Snellman painotti jälkimmäistä seikkaa ilmeisesti siksi, että yhteiskunta oli hänen mukaansa jakautunut syvenevän työnjaon myötä eri yhteiskunta- tai kansanluokkiin. Tästä syystä "modernissa yhteiskunnassa kansan edut ovat niin moninaiset [...], että kuka hyvänsä ei voi tarkastella ja saada selville yhteistä hyvää kaikessa laajuudessaan" (mt., 93). Näin ollen on tarpeen, että keskusteluun osallistuvat eri kansanluokkien edustajat, jotka parhaiten tuntevat omat olonsa. "Juuri tämä erilaisissa yhteiskunnallisissa oloissa elävien kansalaisten joukko muodostaa kunkin kansan ajattelevien ihmisten joukon" (mt,, 94) eli Snellmanin mielessä väikkyneen julkison. Vaikka sen jäsenet puolustaisivat omaa tai luokkansa etua, he sitä "puolustaessaan samalla puolustavat ja edistävät jotakin maalle olennaisen tärkeää etua" (mt.).

Snellman näyttää siis ajattelevan, että vaikka eri oloissa elävien edut ovatkin erilaiset, ne eivät ole sovittamattomaan erilaiset. Tämä implikoi, että näitä erityisetuja syvemmällä täytyy olla yhteinen etuperusta, jonka pohjalta erityisetujen ristiriidat ovat sovitettavissa. Tuona etuperustana ei voine olla muu kuin kansallinen etu. Niinpä vaikka Snellmanin yllä kuvattu käsitys julkisuudesta näyttää ensi katsannolla eroavan etukysymyksen osalta porvarillisen julkisuuden mallista, tämän tulkinnan mukaan se itse asiassa edustaisi tuota mallia korotettuna toiseen potenssiin. Toisin sanoen se olisi tuo malli yleistettynä kansalliseksi suomalaiseksi julkisuudeksi. Tältä pohjalta lähtiessään Snellman ei epäillyt, etteikö eri yhteiskuntapiirien sivistyneistöä edustavan julkison keskusteluissa päädytä asioista järkiperäiseen yhteisymmärrykseen. Edellytyksenä on, että lehdistö

välittää nuo asiat maan ajattelevien ihmisten osallistumisen kohteiksi. Moni tällainen mies osoittaa tämän osallistumalla itse lehtien palstoilla käytävään keskusteluun; toiset toimivat mielipiteensä puolesta pienemmässä piirissä ja järkevin käsitys puheena olevasta 
asiasta voittaa vähitellen kannatusta kunnes lähes kaikki sitä vastustavat äänet vaimenevat. Kun sitten [...] hallintoelimet asettavat tuon kysymyksen eri yhteiskuntaluokkia ja maan eri osia edustaville miehille, he saavat kaikkialla saman vastauksen eikä tällä tavoin meneteltäessä voida erehtyä siitä, mitä yleinen etu tässä tapauksessa vaatii. (Mt., 97.)

Snellmanin näkemystä voidaan toki arvostella idealistisen ylioptimistiseksi sinisilmäisyydeksi, joka sivuuttaa eturistiriitojen todellisen jyrkkyyden ja uskoo vilpittömästi julkisten keskustelujen kommunikatiiviseen toimivuuteen ottamatta huomioon, että ne eivät monesti johda minnekään ja ovat useinkin vain strategista näennäiskeskustelua, jossa pyrkimykset ovat aivan muualla kuin järkiperäisen yhteisymmärryksen saavuttamisessa. Edelleen tuo näkemys oli ajalleen ominaiseen tapaan elitistinen ja sukupuolittunut katsoessaan, että vasta miespuolisen sivistyneistöjulkison kautta "yleisön ääni saa vaikutusta maan yleisten asioiden järjestämisessä" (mt., 95). Miten hyvänsä, kun suomalainen julkisuus alkoi 1860-luvulta lähtien varsinaisesti kehittyä, Snellmanin näkemykset antoivat tuohon kehitykseen oman panoksensa (Puntila 1947). Toisaalta se, kuinka julkisuus tuolloin vastasi ja on sittemmin vastannut hänen teoreettisia visioitaan, on jo kokonaan toinen juttu.

\section{Viitteet}

1 Kiitän informaatikko Margareta Ekmania tässä käytetyn lehtiaineiston kaivamisesta käsille.

2 Näistä uudissanoista muut paitsi julkisuus ovat Schildt-Kilpisen käsialaa. Hakulisen (2000, 455) mukaan sanan julkisuus sepittäjänä tai käyttöön ottajana pidetään Kanawa-lehden toimittajaa Pietari Hannikaista. Sen kantasana julkinen esiintyy suomen kirjakielessä 1500luvulta lähtien (Häkkinen 1987, 79-80). Kohtamäen $(1959,25)$ mukaan Hannikainen perusteli lehtensä tarvetta sillä, että "valistus ja sivistys tarvitsevat edistyäkseen 'kirjallisuutta eli julkisuutta"'. Hannikainen muuten ehdotti termin yleisö sijaan termiä yhteisö (Hakulinen mt., 456). - Schildt-Kilpisen julkisotermiin törmäsin Kohtamäen teoksessa (mt., 157).

3 Sittemmin olemme viljelleet tätä sanaa aina tilaisuuden tullen - yhden jos toisenkin henkilön mieliharmiksi (ks. Pietilä 1999, 2001, 2002a, 2002b, 2003, 2004, 2005; Ridell 1998, 1999a, 1999b, 2000a, 2000b, 2001, 2002, 2003a, 2003b, 2004).

4 Tekstejä oli kaikkiaan 138 - niin monografioita kuin aikakausjulkaisuissa, vuosikirjoissa ja kokoomateoksissa julkaisuja artikkeleita 1980- ja 1990-luvuilta. Termi audience esiintyi kaikissa ja termi public noin puolessa niistä - vajaassa neljäsosassa tekstejä se esiintyi satunnaista säännöllisemmin.

5 Yleisöön viittaavana yleisterminä audience on publicia nuorempi. Palaan tähän kysymykseen edempänä.

6 Julkisuudessa esiintyessään talk show'n osallistujat eroavat toki audiencesta, mutta on eri asia, rakentuuko heistä tällöin public. Livingstone $(2005,32)$ näyttää ajattelevan tällä haavaa niin, että sellaiset"sumeat tai moniselitteiset" ilmiöt kuten "kiihkeä keskustelu talk show'ssa" eivät kuulu publicin alueelle vaan sen ja audiencen väliin kehkeytyneeseen kansalaiskulttuuriin (civic culture).

7 Tosin publicinakin tällainen ryhmä on hänestä yhä osa audiencea, mutta eroaa silti pelkästään vastaanottavasta, vastakaikuna viestimiin muodostuneesta audiencesta.

8 Drotner tosin sanoo, että tanskan julkisuutta tarkoittava offentlighed viittaa normatiivisessa mielessä joukkoon ihmisiä, jotka osallistuvat poliittiseen julkisuuteen, mutta avoimeksi jää, mitä tämä oikeastaan tarkoittaa - sitäkö, että julkisuudesta puhuttaessa tullaan aina puhuneeksi myös siellä toimivista ihmisistä? Vrt. viitteeseen 12.

9 Saksassa tämä yleistermi on Publikum, tanskassa publikum, kreikassa кoívó(koino), sloveniassa občenstvo tai publika ja ranskassa public. Meillähän vastaavana moniulotteisena yleisterminä on toiminut yleisö. 
10 Audience on viitannut jo varsin varhain kuunteluun ja kuulijoihin. OED:n (I 1989, 779) viitteistä päätellen se alkoi yleistyä ylivälineellisenä yleisökäsitteenä 1800-luvun puolivälistä, jolloin reading audience ilmaantui viittaamaan painetun sanan lukijoihin. (ks. myös Abercrombie \& Longhurst 1998, 43-44). McQuailin $(1997,4)$ esityksestä päätellen tavallinen lukijoihin viittaava termi oli tätä ennen reading public. - Kuitenkin varsinaiseksi ylivälineelliseksi yleisötermiksi audience näyttäisi vakiintuneen siis joskus 1920-luvulla.

11 Kirjaa suomentaessani tein sen ratkaisun, että käänsin sisäisesti monimerkityksisen Publikumtermin termillä yleisö silloin, kun se viittasi vastaanottajiin, ja termillä julkiso silloin, kun se viittasi julkisesti keskusteleviin henkilöihin.

12 Hölscherin $(1984,1134-1135)$ käsitehistoriallisen sanakirja-artikkelin mukaan terminologinen muutos käynnistyi 1800-luvun loppupuolella. Julkisuutta merkinnyt Öffentlichkeit alkoi tuolloin merkitä myös siellä toimivia. Tässä merkityksessä se onkin "osittain korvannut vanhemman Publikum-termin". Tässä horisontissa on ymmärrettävää, että Publikum on voinut painottua yhä yksinomaisemmin yleisön merkitseväksi. Vrt. viiteeseen 8.

13 Yleisön yksityistymiseen liittyen Butsch (2000) kertoo, että aiempi äänekäs julkinen meno teattereissa vaimeni, kun teatterinjohtajat pakottivat 1800-luvun puolivälistä alkaen katsojakunnan vaikenemaan kielloin ja erinäisin sopivin tilajärjestelyin. Tämä johti hänen mukaansa teatterikokemuksen psykologiseen yksityistymiseen.

14 Tarkentaen: yleisön jäseninä ihmiset eivät asetu samanlaiseen vuorovaikutukseen kuin julkison jäseninä vaan solmiutuvat sosiaalisen suhteeseen elleivät jopa vuorovaikutukseen viestimen ja siellä esiintyvien kanssa (ks. K. Pietilä 1985 ja 1998; K. Pietilä \& Sondermann 1994, 15-57). - Korostettakoon väärinkäsitysten välttämiseksi, että yleisön asema viestinnän vastaanottajana ja kohteena on rakenteellinen. Tämän aseman rajoissa yleisön jäsenet voivat toki olla aktiivisia, esimerkiksi lukea viestinten antia vastakarvaan ja tulkita sitä omilla tavoillaan, mutta jos he saavat siitä kimmokkeen puuttua julkisesti johonkin asiaan, he siirtyvät julkisorooliin.

15 Tuon luonnehdinnan mukainen public on lähempänä yhteiskunnallista liikettä kuin julkisoa esimerkiksi Blumerin mielessä. On toki huomattava, että julkisot voivat päättää päivänsä paitsi hajoamalla myös vakiintumalla, jolloin ne muuttuvat julkisoista vaikkapa juuri yhteiskunnallisiksi liikkeiksi. Tällaiset liikkeet voivat taas olla osa laajempaa julkisoa, joka kattaa esimerkiksi liikkeeseen kuulumattomat sympatisoijat, liikkeen vastavoimat jne.

16 Warner (2002) käyttää esityksessään termiä public ilmeisen moniselitteisesti. Hän näyttää viittaavan sillä yhtäältä julkiseen diskurssitilaan, jota sitä edustavat tekstit tuottavat, ja toisaalta noihin teksteihin huomiota kiinnittäviin ihmisiin. Omassa käsitteistössäni diskurssia rakentavat tekstit edustaisivat julkisoa ja niihin huomiota kiinnittävät ihmiset yleisöä. Tietysti jos jollain aikahetkellä yleisöityneestä joukosta jotkut puuttuvat seuraavana aikahetkenä julkisin tekstein kyseiseen diskurssiin, he julkisoituisivat näiden tekstiensä osalta. Julkisous on näkyvää, yksityinen yleisöys sinällään ei ole.

\section{Kirjallisuus}

Abercrombie, Nicholas \& Brian Longhurst (1998) Audiences. London: Sage.

Alapuro, Risto \& Henrik Stenius (1989) Kansanliikkeet loivat kansakunnan. Teoksessa Risto Alapuro ym. (toim.) Kansa liikkeessä, 7-49. Helsinkił Kirjayhtymä.

Ang, Ien (1991) Desperately Seeking the Audience. London: Routledge.

Blumer, Herbert (1946/1999) Joukko, massa ja julkiso. Tiedotustutkimus 22 (3), 14-26.

Blumer, Herbert (1947/1965) Public Opinion and Public Opinion Polling. Teoksessa Daniel Katz et al. (eds.) Public Opinion and Propaganda, 70-78. New York: Holt, Rinehart \& Winston.

Butsch, Richard (2000) Introduction: Participative Public, Passive Private? Teoksesta Richard Butsch, The Making of American Audiences. Cambridge: Cambridge University Press. (http://www.rider.edu/grid/homepages/faculty/butsch/audiences.htm [20.12.2004])

Carey, James W. (1989) Communication as Culture. Boston MA: Unwin Hyman.

Corner, John (1991) Meaning, Genre and Context. Teoksessa James Curran \& Michael Gurevitch (eds.) Mass Media and Society, 267-284. London: Edward Arnold.

Dahlgren, Peter (1995) Television and the Public Sphere. London: Sage.

Dayan, Daniel (2001) The Peculiar Public of Television. Media, Culture \& Society 23 (6), 743-765.

Dayan, Daniel (2005) Mothers, Midwives and Abortionists. Teoksessa Sonia Livingstone (ed.)

Tiedotustutkimus $2006 \div 4$ 
Audiences and Publics, 43-76. Bristol: Intellect Books.

Dewey, John (1927) The Public and Its Problems. New York: Henry Holt.

Fiske, John (1994) Audiencing: Cultural Practice and Cultural Studies. Teoksessa Norman K.

Denzin \& Yvonna S. Lincoln (eds.), Handbook of Qualitative Research, 189-198.

Thousand Oaks: Sage.

Habermas, Jürgen (1962/2004) Julkisuuden rakennemuutos. Tampere: Vastapaino.

Habermas, Jürgen (1990/2004) Jälkisanat vuoden 1990 uusintapainokseen.

Teoksessa Jürgen Habermas, Julkisuuden rakennemuutos, 357-397. Tampere: Vastapaino.

Habermas, Jürgen (1997) Faktizität und Geltung (5. Aufl.). Frankfurt am Main: Suhrkamp.

Hakulinen, Lauri (2000) Suomen kielen rakenne ja kehitys (5 p.) Helsingin yliopisto,

Suomen kielen laitos.

Hartley, John (1987) Invisible Fictions. Textual Practice 1 (2), 121-137.

Hellman, Heikki (1999) Legitimations of Television Programme Politics. Teoksessa Pertti Alasuutari (ed.) Rethinking the Media Audience, 105-129. London: Sage.

Häkkinen, Kaisa (toim.) (1987) Nykysuomen sanakirja, osa 6, etymologinen sanakirja. Porvoo/Helsinki: WSOY.

Hölscher, L. (1984) Öffentlichkeit. Teoksessa Joachim Ritter \& Karlfried Gründer (Hrsg.), Historisches Wörterbuch der Philosophie, Band 6. Darmstadt: Wissenschaftliche Buchgesellschaft.

Jensen, Klaus Bruhn (1990) Television Futures. Critical Studies in Mass Communication 7 (2), 129-146.

Kohtamäki, Ilmari (1959) Pietari Hannikaisen "Kanava": uudenaikaisen lehdistömme ladunavaaja. Helsinki: Suomalaisen Kirjallisuuden Seura.

Koivunen, Anu \& Mikko Lehtonen (2005) "Joskus on kiva olla vähemmän aikuinen". Tiedotustutkimus 28 (2), 4-27.

Kunelius, Risto (1997) Viestinnän vallassa. Helsinki: WSOY.

Laine, Markus \& Lasse Peltonen (2003) Ympäristökysymys ja aseveliakseli. Tampere: Tampere University Press.

Lehtinen, Ari \& Pertti Rannikko (1994) Pasilasta Vuotokselle. Helsinki: Gaudeamus.

Livingstone, Sonia (ed.) (2005) Audiences and Publics. Bristol: Intellect Books.

Livingstone, Sonia (2005) On the Relation between Audiences and Publics. Teoksessa Sonia Livingstone (ed.) Audiences and Publics, 17-41. Bristol: Intellect Books.

Livingstone, Sonia \& Peter Lunt (1994) Talk on Television. London: Routledge.

McCombs, Maxwell (1998) News Influence on Our Pictures of the World.

Teoksessa Roger Dickinson et al. (ed.) Approaches to Audiences, 25-35. London: Arnold.

McQuail, Denis (1987) Mass Communication Theory (2nd ed.). London: Sage.

McQuail, Denis (1997) Audience Analysis. Thousand Oaks CA: Sage.

Mills, C. Wright (1956/1999) The Mass Society. Teoksessa Robert Jackall (ed.) Propaganda, 71-101. Houndmills: The Macmillan Press.

Mills, C. Wright (1963) Mass Media and Public Opinion. Teoksessa C. Wright Mills, Power, Politics and People, 577-598. New York: Oxford University Press.

Mosco, Vincent \& Lewis Kaye (2000) Questioning the Concept of Audience. Teoksessa Ingunn Hagen \& Janet Wasko (eds.) Consuming Audiences?, 31-46. Cresskill NJ: Hampton Press.

Nieminen, Hannu (2006) Kansa seisoi loitompana: Kansallisen julkisuuden rakentuminen Suomessa 1809-1917. Tampere: Vastapaino.

The Oxford English Dictionary (1989) Volumes I \& XII. Oxford: Clarendon Press.

Park, Robert E. (1904/1972) The Crowd and the Public and Other Essays (ed. by Henry Elsner Jr.). Chicago: The University of Chicago Press.

Pietilä, Kauko (1985) Joukkotiedotuksen sosiologiaa pelastamassa. Tiedotustutkimus 8 (3), $1-12$.

Pietilä, Kauko (1998) Massa ja yleisö journalismin historiassa. Teoksessa Ullamaija Kivikuru \& Risto Kunelius (toim.) Viestinnän jäljillä, 57-78. Helsinki: WSOY.

Pietilä. Kauko \& Klaus Sondermann (1994) Sanomalehden yhteiskunta. Tampere: Vastapaino.

Pietilä, Veikko (1999) Julkiso ja yleisö. Tiedotustutkimus 22 (3), 4-13.

Pietilä, Veikko (2000) "The Public" as a Construct in the Discourses on Audience. Julkaisematon käsikirjoitus.

Pietilä, Veikko (2001) Yleisönosasto ja Internet keskusteluareenoina. Tiedotustutkimus 24 (2), 18-33.

Pietilä, Veikko (2002a) Siltasotaa Tampereella. Kunnallistieteellinen aikakauskirja 30 (2), 136-154. 
Pietilä, Veikko (2002b) Verkkokeskusteluareenat - deliberatiivista julkisuuttako? Politiikka 44 (4), 343-354.

Pietilä, Veikko (2003) Careyn saatteeksi. Tiedotustutkimus 26 (2), 4-5.

Pietilä, Veikko (2004) Kääntäjän alkusanat. Teoksessa Jürgen Habermas, Julkisuuden rakennemuutos. Tampere: Vastapaino.

Pietilä, Veikko (2005) Kansalaisvaikuttaminen ja julkinen keskustelu. Yhdyskuntasuunnittelu 43 (1), 90-95.

Pietilä, Veikko ja Seija Ridell (1998) Julkea ehdotus. Tiedotustutkimus 21 (1), 95.

Price, Monroe E. (1995) Television, the Public Sphere and National Identity. Oxford: Clarendon Press.

Price, Vincent (1992) Communication Concepts 4. Public Opinion. Newbury Park CA: Sage.

Puntila, L.A. (1947) Yleisen mielipiteen muodostuminen Suomessa 1860-luvulla. Teoksessa Historiallinen arkisto 52, 455-521.

Reunanen, Esa (2003) Budjettijournalismi julkisena keskusteluna. Tampere: Tampere University Press.

Ridell, Seija (1998) Tolkullistamisen politiikkaa. Acta Universitatis Tamperensis 617.

Ridell, Seija (1999a) Tutkimus julkisoa tuottamassa. Tiedotustutkimus 22 (3), 28-41.

Ridell, Seija (1999b) Verkkoviestinnän haasteet journalismin yleisösuhteelle - tapaus LOCALITY-hanke. Teoksessa Mari Maasilta (toim.) Journalismin muutoskaruselli, 128-141. Tampereen yliopisto, Journalismin tutkimusyksikkö.

Ridell, Seija (2000a) Ei journalismi ole tärkeää, julkisuus on. Tiedotustutkimus 23 (1), 144-155.

Ridell, Seija (2000b) Kansalaisjulkisuuden kokeilua verkossa. Teoksessa Ari Heinonen ym., Verkkotorilla, 55-98. Tampereen yliopisto, Tiedotusopin laitos/Journalismin tutkimusyksikkö, julkaisusarja C:32.

Ridell, Seija (2001) Internet paikallisena julkisuustilana. Kunnallistieteellinen aikakauskirja 29 (4), 341-360.

Ridell, Seija (2002) Media ja tutkimuksen yhteiskuntavastuu. Tiedotustutkimus 25 (4), 54-57.

Ridell, Seija (2003a) Kansalaislajityypit verkkodemokratian rakennuspuina. Alue ja ympäristö 32 (1), 11-22.

Ridell, Seija (2003b) Toimijuus mediayhteiskunnassa. Tiedotustutkimus 26 (2), 67-70.

Ridell, Seija (2004) Median julkisuustiloja kartoittamassa. Tiedotustutkimus 27 (2), 4-24.

Ridell, Seija (2005) Maankäyttöpeliä mediatilassa. Yhdyskuntasuunnittelu 43 (1), 28-48.

Rättilä, Tiina (2001) Kansalaistuva politiikka? Politiikka 43 (3), 190-207.

Simmel, Georg $(1908,1917 / 1999)$ Pieni sosiologia. Helsinki: Tutkijaliitto.

Snellman, J.V. (1844/2005) Julkinen sana. Teoksessa J.V. Snellman, Kootut teokset, osa 6, 304-312. Helsinki: Opetusministeriö. (http://www.vnk.fi/tiedostot/pdf/fi/81395.pdf [26.8.2005])

Snellman, J.V+ (1846/2005) Yleinen mielipide. Teoksessa J.V. Snellman, Kootut teokset, osa 9, 92-97. Helsinki: Opetusministeriö. (http://www.vnk.fi/tiedostot/pdf/fi/82959.pdf $(26.8 .2005])$

Sutela, Marja (2001) Kuntalaisten suora osallistuminen paikallispolitiikkaan. Kunnallistieteellinen aikakauskirja 29 (4), 378-388.

Tarde, Gabriel (1898, 1901/1969) On Communication and Social Influence (ed. by Terry N. Clark). Chicago: The University of Chicago Press.

Turner, Ralph H. \& Lewis M. Killian (1972) Collective Behavior (2nd ed.). Englewood Cliffs NJ: Prentice-Hall.

Turow, Joseph (1992), Media Systems in Society. New York: Longman.

Warner, Michael (2002) Publics and Counterpublics. Public Culture 14 (1), 49-90. 